\title{
Outpatient Electronic Medical Records
}

\author{
Tominanto \\ APIKES Citra Medika Surakarta \\ Surakarta, Indonesia \\ tommynanto@gmail.com
}

\author{
Eko Purwanto \\ STIMIK Duta Bangsa Surakarta \\ Surakarta, Indonesia \\ ekopurwanto_stmik@yahoo.co.id
}

\author{
Novita Yuliani \\ APIKES Citra Medika Surakarta \\ Surakarta, Indonesia \\ yuliani_novita@yahoo.co.id
}

\begin{abstract}
The implementation of outpatient medical records in most hospitals in Indonesia is still manual or paperbased. This manual medical records has weaknesses, including: 1) requiring a large storage area, 2) requiring a long time for the process of searching, sorting, sweeping and providing documents, 3) requiring many people to access, 4) having high risk of document damage and 5) having very low data security. This condition can lead to less optimal patient treatment services and even wrong medical treatment that are detrimental to the patient's health. As a solution to these problems, in this study is developed an outpatient electronic medical records model using the Waterfall method, PHP programming language and MySQL database with development stages: system requirements analysis, design system, implementation and testing system. The results of this study are outpatient electronic medical records software which consists of: 1) patient data input, 2) examination history process, 3) physical examination input, 4) diagnostic input, 5) action input and 6) drug administration input. This software can store and restate outpatient health history information more quickly and accurately so that outpatient medical records services can run more optimally.
\end{abstract}

Keywords-electronic medical records, outpatient, waterfall

\section{INTRODUCTION}

Medical records according to the Minister of Health Regulation No.269 / MENKES / PER / III / 2008 is files containing notes or documents about patients, examinations, treatments, actions and other services provided to patients during the treatment period [1]. The purpose of medical records is to support the achievement of orderly administration in order to improve health services. Without the support of a good and correct medical records processing system, it will not achieve the orderly administration as expected. Medical Records is also a compilation of facts about a patient's health and illness, which includes documented data about current and past illnesses and treatment that has been and will be carried out by health professionals in writing [2].

Electronic Medical Records or commonly called EMR is the use of information technology devices for collecting, storing, processing and accessing data stored in patient medical records in health services in a database management system that collects various sources of medical data [3]. Electronic medical records is stored and used by electronic means. Electronic medical records that is focused on outpatients and in patients is a system for integrating clinical diagnosis and treatment information [4].

The implementation of outpatient medical records in most hospitals in Indonesia is still manual or paper-based.
This manual medical record has weaknesses, including: 1) requiring a large storage area, 2) requiring a long time for the process of searching, sorting, sweeping and providing documents, 3) requiring many people to access, 4) having high risk of document damage and 5) having very low data security. This condition can lead to less optimal patient treatment services and even wrong medical treatment (mall practice) that are detrimental to the patient's health. An alternative solution to this weakness is that it is necessary to develop management of outpatient medical records electronically.

Research on the development of electronic medical records has been carried out by many researchers, including researches [4], [5], [6], [7], [8]. Those studies developed an electronic medical records to solve the problem of managing medical records using various methods, but most of them concluded that electronic medical records could improve patient health services. While in this study develops an electronic medical records model that focuses on outpatient medical records service problems using the Waterfall software development method [9], PHP programming language and MySQL database.

\section{MATERIALS AND METHODS}

Developing outpatient electronic medical records software method applies the waterfall stage as shown in Figure. 1:

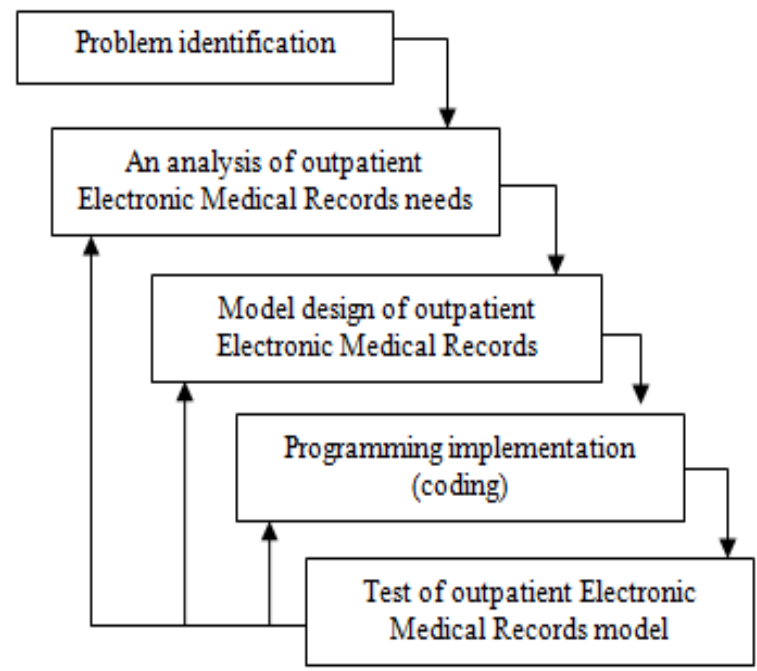

Figure. 1. Waterfall method of outpatient Electronic Medical Records

The stages of developing the waterfall system in Fig. 1 are carried out sequentially from the identification, analysis, design, implementation and testing stages. However, when a 
stage finds a problem, it can be repeated back to the previous stage or to an earlier stage, then proceed to the next stage in sequence until the outpatient electronic medical records software is successful in the system testing phase.

\section{RESULTS AND DISCUSSION}

\section{A. System Analysis and Design}

The results of the analysis and system design in this study are presented in the form of data flow diagrams (DFD) : context diagram and level 1 DFD.

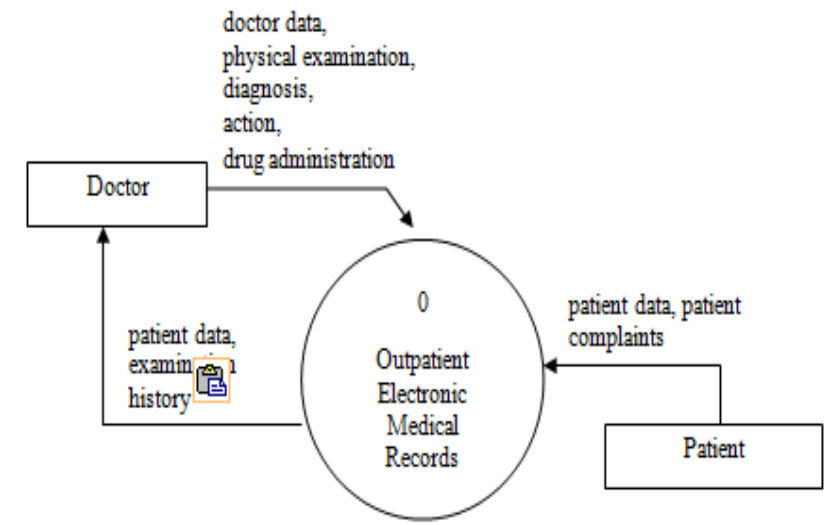

Figure 2. Context diagram

Fig. 2 shows that the electronic medical records process is related to two entities, namely doctors and patients. Patient's entity provide input in the form of patient data and patient complaints about the illness. The doctor's entity when conducting the examination can read the patient's data and previous examination history, then enter the examination consisting of physical examination, diagnosis, action and drug administration.

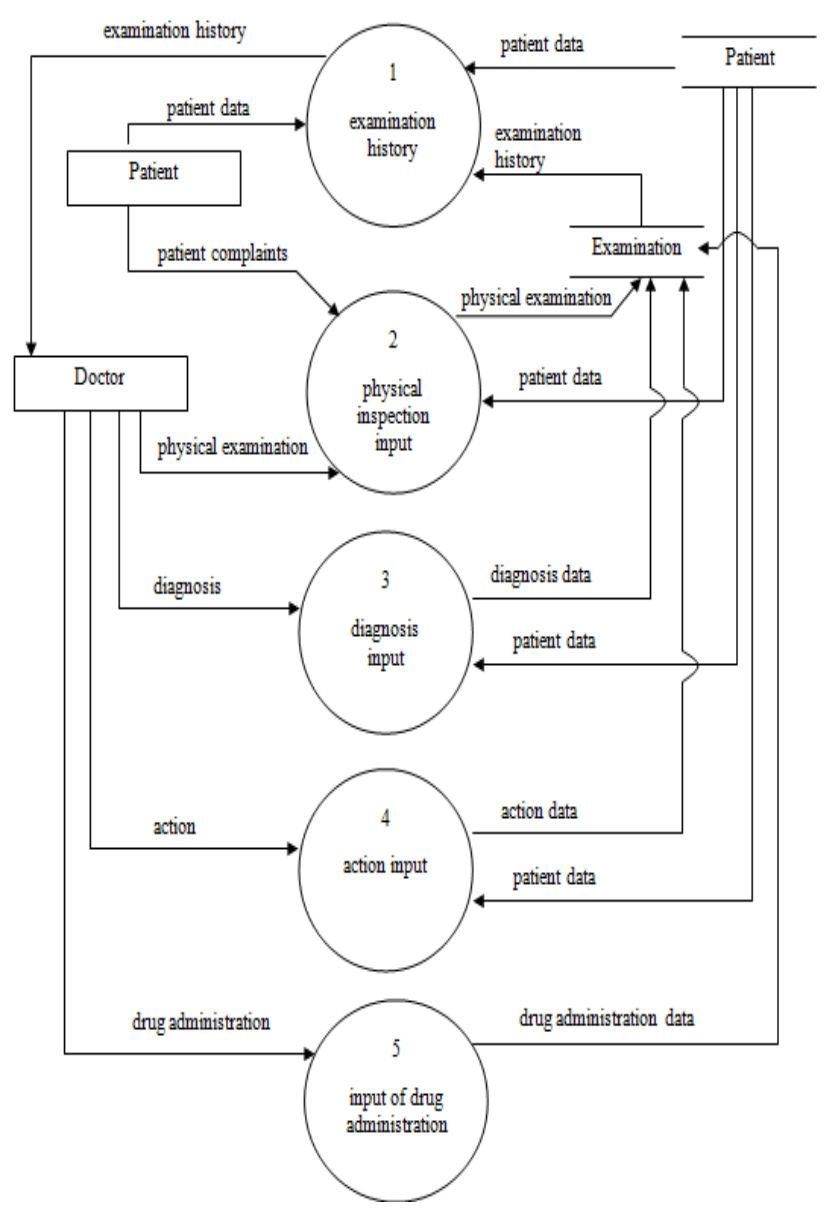

Figure. 3. level 1 DFD

This level 1 DFD breaks down one process in the context diagram into five processes here are the detailed processes :

1. The examination history process is reading process of doctor's examination history by inputting the patient's data, reading the patient's data from the patient table and reading the examination history from the check table.

2. The physical inspection input process is the process of inputting patient complaints and physical examination results that are stored in the examination table.

3. The diagnosis input process is the process of inputting the doctor's diagnosis into the system that is stored in the examination table.

4. The action input process is the process of inputting the doctor's actions into the system that is stored in the examination table.

5. The input process for drug administration is the process of inputting drugs given by doctors to patients into the system that is stored in the examination table.

\section{B. System Implementation}

The design of this outpatient electronic medical records is implemented with the PHP programming language and MySQL database. The results of the implementation are as follows :

1. Patient data input

The patient data input form is as shown in Fig. 4 below: 


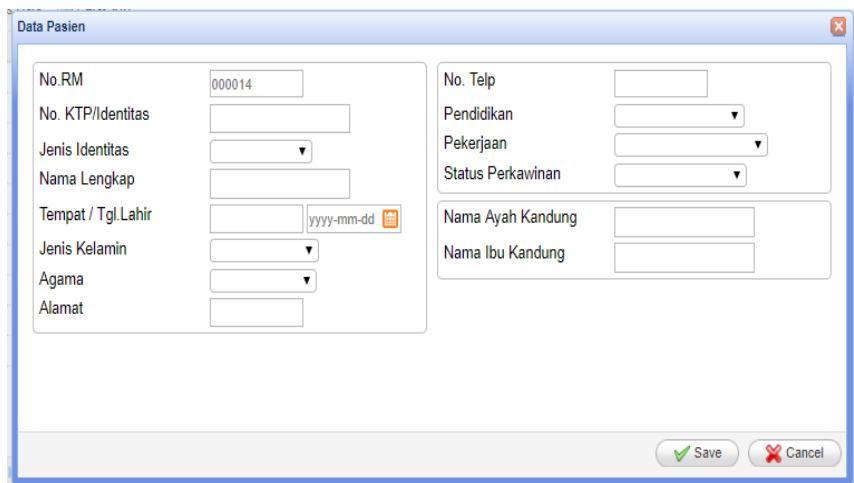

Figure 4. The patient data input form

The patient data input form is used to input the patient's social identity with data attributes: medical records number, number and type of identity card, full name, place and date of birth, gender, religion, address, telephone number, education, occupation, marital status, biological father's name and biological mother's name. The social data of patients who have been inputted are stored in the patient table on the electronic medical record database.

\section{Physical examination input}

Physical examination input forms such as Fig. 5 are used by doctors to input the results of physical examinations and patient complaints. The attributes of the data entered are patient complaints, height, weight, heart rate, blood pressure, body temperature, breath, and the results of the SOAP (Subject, Object, Assessment Plan) examination. This physical examination data is stored in the examination table on the electronic medical record database.

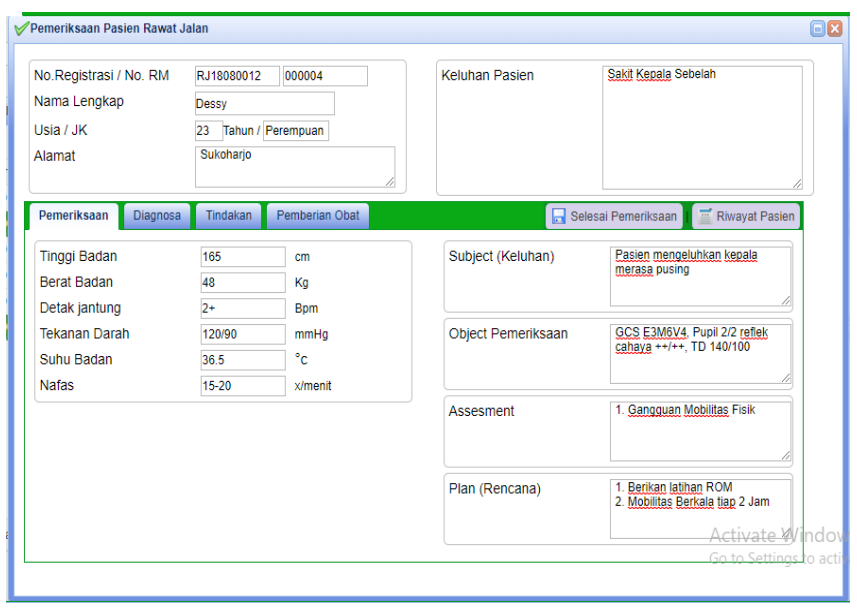

Figure 5. Physical examination input forms

\section{Diagnosis input}

The diagnosis input form is shown in Fig. 6 below:

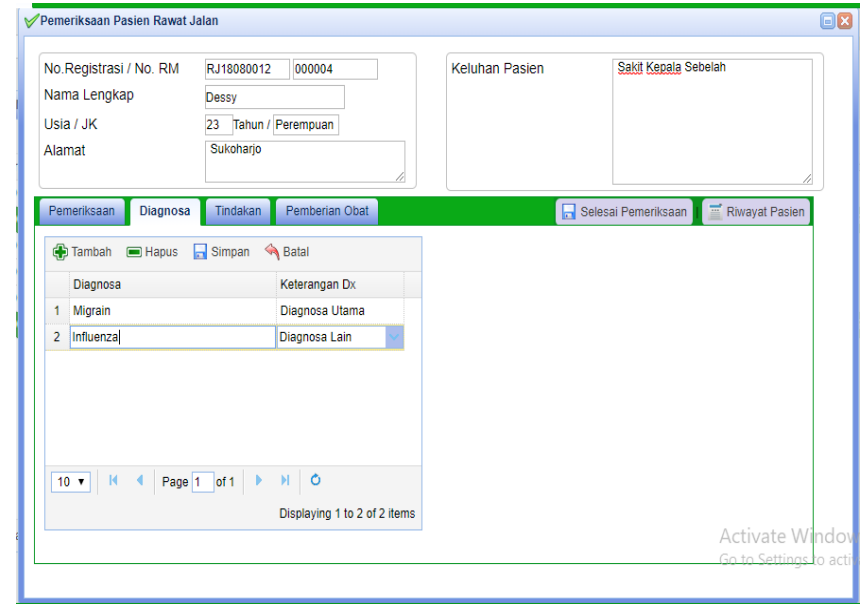

Figure 6. The diagnosis input form

The diagnosis input form is used to input the doctor's diagnosis which consists of a primary diagnosis or an additional diagnosis or another. The diagnosis data that has been inputted is stored in the examination table on the electronic medical record database.

\section{Action input}

Action input form is shown in Fig. 7 below:

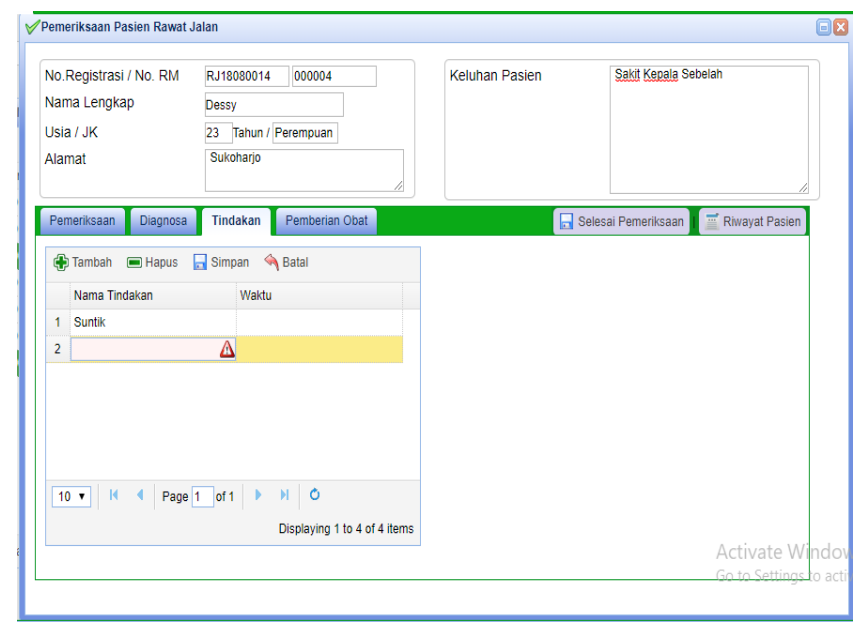

Figure 7. Action input form

The action input form as shown in Fig. 7 is used by doctors to input the actions or therapies given by the doctor to the patient. The attribute of the action data that is inputted with the type of action and the time of execution of the action. The results of input actions are stored in the examination table on the electronic medical records database.

\section{Drug administration input}

Drug administration input is shown in Fig. 8 below : 


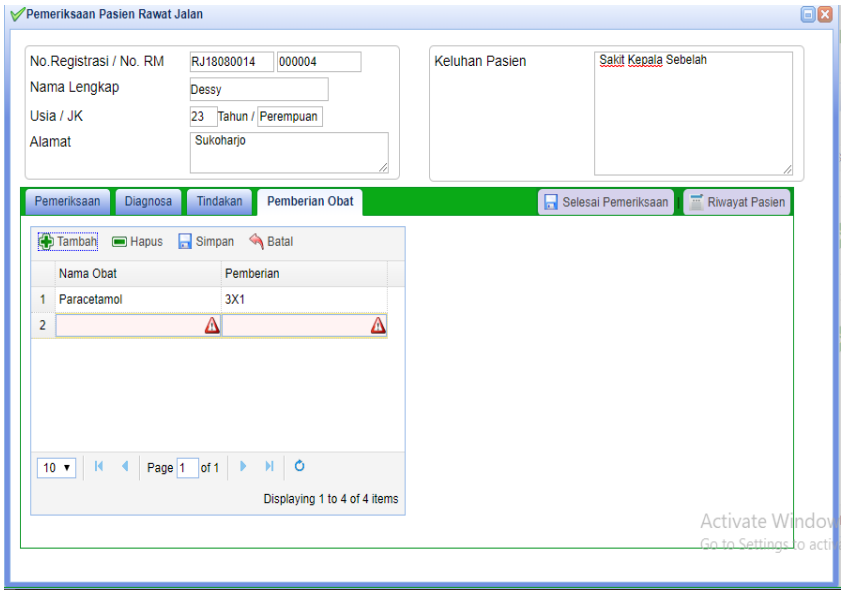

Figure 8. Drug administration input form

The drug administration input form is used by doctors to input drugs given by doctors to patients. As for the attributes of drug administration data that is inputted with the name of the drug and administration or how to take medicine. The results of drug administration input are stored in the examination table on the electronic medical records database.

\section{Testing System}

Testing of electronic medical records software applies the Black Box Testing test method by emphasizing functional program testing and input and output data [10]. System testing results are shown in Table 1 below:

\section{TABLE 1. PROGRAM TESTING RESULTS}

\begin{tabular}{llcl}
\hline No & \multicolumn{1}{c}{ Form Name } & $\begin{array}{c}\text { Number of } \\
\text { errors }\end{array}$ & Information \\
\hline 1 & login/password form & 0 & Valid \\
2 & Patient input form & 0 & Valid \\
3 & Registration input form & 0 & Valid \\
4 & examination history form & 0 & Valid \\
5 & $\begin{array}{l}\text { Physical examination } \\
\text { input forms }\end{array}$ & 0 & Valid \\
6 & Diagnosis input form & 0 & Valid \\
7 & Action input form & 0 & Valid \\
8 & Drug administration form & 0 & Valid \\
\hline
\end{tabular}

The test is carried out by testing to input data 20 times for each process. All trials show that electronic medical records software runs well without errors and the data entered is also stored validly in each table on the basis of electronic medical records data and can be read or can produce a valid output.

\section{CONCLUSION}

The conclusion of this paper is outpatient electronic medical records software that is developed with the waterfall method and using the PHP programming language and MySQL database, the software has several processes: patient data input, examination history process, physical examination input, diagnostic input, action input and drug administration input. This software can store and restate outpatient health history information more quickly and accurately so that outpatient medical records services can run more optimally.

\section{ACKNOWLEDGMENT}

This paper is one of the publications from the research results of the PTUPT scheme funded by the Directorate of Research and Community Service, Ministry of Research, Technology and Higher Education in 2018.

\section{REFERENCES}

[1] "Peraturan Menteri Kesehatan Republik Indonesia No 269/Menkes/PER/2008 tentang Rekam Medis," Menteri Kesehatan. pp. 1-7, 2008.

[2] Y. Puspitasari and B. E. Purnama, "Sistem Informasi Rekam Medis Pasien Rawat Jalan Dan Observasi Pada Puskesmas Pringkuku Kabupaten Pacitan,” Indones. J. Netw. Secur., pp. 1-6, 2013.

[3] W. Handiwidjojo, "Rekam medis elektronik," Eksis, vol. 2, no. 1, pp. 36-41, 2009

[4] P. Chuan, "Design of Electronic Medical Record System Based on Cloud Computing Technology," TELKOMNIKA Indones. J. Electr. Eng., vol. 12, no. 5, pp. 4010-4017, 2014.

[5] C. Pan, J. Hu, and J. Shi, "Partitioning of Oracle Application in Structured Electronic Medical Records," TELKOMNIKA Indones. J. Electr. Eng., vol. 12, no. 7, pp. 5693-5698, 2014.

[6] A. N. Kho et al., "Use of diverse electronic medical record systems to identify genetic risk for type 2 diabetes within a genome-wide association study," J. Am. Med. Informatics Assoc., vol. 19, no. 2, pp. 212-218, 2012.

[7] B. E. Purnama and A. Ashari, "Distributed Data Patient In Medical Record Information System," J. Sci. Technol. Res., vol. 2, no. 8, 2013.

[8] Y. U. Khasanah, "Perencanaan Sistem Rekam Medis Berdasarkan Input Puskesmas Banguntapan II Kabupaten Bantul Tahun 2011," KES MAS, vol. 5, no. 1, pp. 55-71, 2011.

[9] G. W. Sasmito, "Penerapan Metode Waterfall Pada Desain Sistem Informasi Geografis Industri Kabupaten Tegal,” J. Inform. Pengemb. IT, vol. 2, no. 1, pp. 6-12, 2017.

[10] M. Komarudin, "Pengujian Perangkat Lunak Metode Black-Box Berbasis Equivalence Partitions Pada Aplikasi Sistem Informasi Sekolah," Mikrotik, vol. 6, no. 1, 2016. 